\title{
«DDUCAR CRISTIANAMENTE \\ A LOS OBREROS». ACTIVIDAD EDUCATIVA EN LA DIÓCESIS DE ZAMORA DURANTE LA RESTAURACIÓN: LAS ESCUELAS DE ADULTOS Y EL CÍRCULO CATÓLICO DE OBREROS
}

\section{"Christian Education for Workers». The educational activity of the diocese of Zamora during the Restoration: school for adults and the Catholic Circle of Workers}

\author{
Miguel-Ángel Hernández Fuentes \\ Universidad de Salamanca \\ Correo-e: miguelangelhernandez@usal.es
}

Recepción: io de noviembre de 20ı6. Envío a informantes: is de diciembre de 2016.

Aceptación definitiva: 5 de junio de 2017

Resumen: A lo largo del siglo xix brotó una corriente en el seno de la Iglesia que vino a denominarse catolicismo social. Algunas de las manifestaciones más notables de esta acción social de la Iglesia fueron la promoción de la educación popular y de la instrucción religiosa, entendida por los prelados como el camino para conseguir mejorar la situación moral de España. Fruto temprano de esta propuesta de la Iglesia fue la creación de unas escuelas destinadas a la educación de adultos con las que se pretendía dar una respuesta a la cuestión obrera desde el terreno educativo. El presente artículo analiza el discurso episcopal que sirvió de soporte ideológico para la implantación de estos centros educativos y presenta la implantación y el desarrollo de dos iniciativas que promovieron la educación del proletariado en la diócesis de Zamora: las Escuelas Dominicales y Nocturnas y el Círculo Católico de Obreros.

Palabras clave: Escuelas de Adultos; Círculos Católicos de Obreros; Catolicismo social; cartas pastorales; Zamora. 


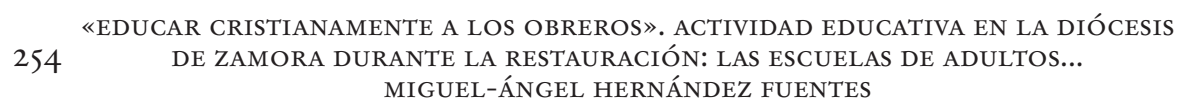

Aвstract: Throughout the nineteenth century came a stream within the Church that came to be known as Social Catholicism. Some of the most striking developments of this social action of the Church were the promotion of popular education and religious instruction, understood by the prelates as the best way to improve the moral situation of Spain. An early and fruitful outcome of this proposal was the creation of schools for adult education with which it pretended to solve the labor situation from an educational level. This article analyzes the episcopal discourse that served as an ideological support for the implementation of these schools and also presents the implementation and development of two initiatives that promoted the education of the proletariat in the diocese of Zamora: the Sunday and Night Schools and the Catholic Circle of Workers.

Key words: Adult Schools; Catholic Circle of Workers; Social Catholicism; pastoral letters; Zamora.

\section{Introducción}

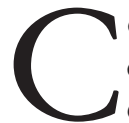

ON LA LlEGADA DE LA INDUSTRIALIZACión surgieron nuevos problemas que convirtieron la sociedad decimonónica en una sociedad de contrastes e interrogantes profundos. La nueva organización del trabajo, la mecanización laboral, la aparición de la empresa industrial y el surgimiento de masas de trabajadores dependientes del capitalismo generaron un conflicto denominado la cuestión obrera. Era necesario ofrecer respuestas ante una nueva realidad que producía desequilibrio social, injusticia y marginación y estas llegaron desde múltiples instancias. Entre ellas, la Iglesia reaccionó mediante la promoción de una serie de iniciativas que constituyeron lo que se ha conocido como el catolicismo social y que tuvo en la educación popular uno de sus principales exponentes. Los primeros pasos de este movimiento social católico se dieron en Bélgica, Alemania o Francia y encontraron respaldo oficial de la Santa Sede en i89i con la publicación de la encíclica Rerum novarum ${ }^{\text {. }}$. Los cambios que este documento pontificio produjo en la acción pastoral de la Iglesia fueron importantes, pero su publicación no solo señalaba los nuevos pasos a seguir, sino que la propuesta papal sancionaba el camino emprendido por numerosos proyectos sociales surgidos en las décadas precedentes. Entre ellos se encontraban los Círculos Católicos de Obreros y las Escuelas de Adultos, dos instituciones que formaban parte de los proyectos católicos vinculados a la educación popular. No en vano, uno de los mayores logros del catolicismo social estuvo ligado al terreno educativo y supuso la fundación de numerosas congregaciones religiosas e instituciones católicas dedicadas a promover la instrucción elemental y a luchar contra la ignorancia religiosa y cultural.

Pazos, Antón M. (coord.): Un siglo de catolicismo social en Europa (I89I-I99I), Pamplona, Ediciones Universidad de Navarra, 1993; Rerum novarum: écriture, contenu et réception d'une encyclique. Actes du colloque international organisé par l'École française de Rome et le Greco (I99I), Roma, Ecole Française de Rome, 1997. 
«EDUCAR CRISTIANAMENTE A LOS OBREROS». ACTIVIDAD EDUCATIVA EN LA DIÓCESIS DE ZAMORA DURANTE LA RESTAURACIÓN: LAS ESCUELAS DE ADULTOS... MIGUEL-ÁNGEL HERNÁNDEZ FUENTES

En este asunto, la Iglesia respondía desde sus propios principios ante uno de los problemas sociales más importantes que gravitaban sobre la sociedad del siglo XIx: el analfabetismo. Alejandro Tiana Ferrer ha señalado que esta carencia de instrucción elemental, sentida de modo especial entre las clases populares, supuso la reacción por parte de tres instancias sociales que desarrollaron sus proyectos pedagógicos desde postulados bien distintos: los reformistas españoles, los católicos sociales y el movimiento obrero ${ }^{2}$. Según este autor, la primera propuesta nacía de un sector de la burguesía que propuso una serie de estrategias conducentes a la corrección de injusticias y desequilibrios sociales con las que se pretendía neutralizar la amenaza revolucionaria de las clases trabajadoras. La segunda propuesta está representada por las diversas iniciativas promovidas por la Iglesia, que, desde una perspectiva pastoral, colaboró notablemente en la educación de las clases trabajadoras y la tercera estaba integrada por los líderes e intelectuales vinculados al movimiento obrero, quienes impulsaron sus propios proyectos pedagógicos. Entre ellos nos interesa aquí el estudio del segundo agente educativo, la Iglesia, y el análisis de uno de sus proyectos educativos más tempranos: las Escuelas Dominicales y de Adultos. No se trataba de una iniciativa exclusivamente católica, pues la existencia de este tipo de centros había sido incluida en el articulado de las leyes educativas, pero la propuesta católica tenía unos fines específicos y propios que es preciso comprender en el contexto del catolicismo social que se estaba desarrollando en toda Europa.

En la diócesis de Zamora la publicación de la Rerum novarum fue saludada por el obispo Tomás Belestá con una extensa pastoral en la que se invitaba a su lectura y a la puesta en práctica de sus directrices ${ }^{3}$. Sin embargo, en los años previos a su publicación ya se habían desarrollado en la ciudad algunas propuestas sociales encaminadas a la educación de las clases trabajadoras. En i883, casi una década antes de ser publicado el texto leonino, habían comenzado su actividad en Zamora las Escuelas Dominicales y de Adultos, patrocinadas por el obispo diocesano con el concurso inicial del Ayuntamiento, que poco después abandonó el proyecto. No se trataba de un proyecto totalmente nuevo. Dichas escuelas retomaban otras iniciativas anteriores cuyo estudio nos resulta interesante y nos ayudará a conocer mejor esta parcela de educación social en la España de la Restauración. No abundan los estudios locales sobre estos centros. Muchos se quedan en las estadísticas oficiales publicadas por diversas instituciones que son siempre fragmentarias e incompletas ${ }^{4}$. A falta de un mayor número de monografías, estos datos estadísticos constituyen un importante punto de partida, pero cada vez se hace más necesario el estudio de estas instituciones a nivel local. Tras el extenso trabajo de José Andrés Gallego dedicado al programa social católico en

Tiana Ferrer, Alejandro: «Movimiento obrero y educación popular en la España Contemporánea», Historia Social, 27 (1997), pp. I3I-I33.

3 Belestá Cambeses, Tomás: «Carta pastoral sobre la cuestión obrera», Boletín Eclesiástico del Obispado de Zamora (en adelante BEOZA), 29 (I89I), p. 232.

Así lo reconoce VeGa GiL, Leoncio: «Las fundaciones benéfico-docentes y la educación y formación del obrero en España (I899-1972)», Historia de la Educación, I8 (1999), p. I58. 


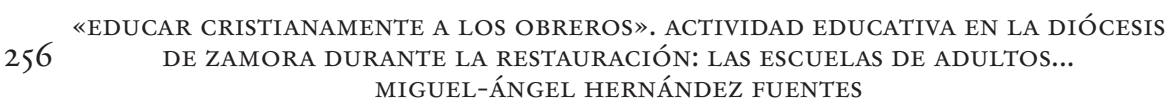

nuestro país y publicado hace varias décadas, disponemos de un marco apropiado para comprender la acción social de la Iglesia en Españas. Sin embargo, su obra sigue reclamando más estudios locales que nos permitan hacer una valoración más ajustada de los logros y de los fracasos que estas iniciativas sociales aportaron al terreno educativo y así lo han señalado diversos autores ${ }^{6}$.

Ciertamente no es fácil elaborar este trabajo, pues la escasez de fuentes hace difícil una aproximación adecuada a la actividad de estos centros educativos. No hemos localizado los libros de matrícula, ni los programas académicos, ni otras fuentes propias de las escuelas que estimamos perdidas. Por ello, hemos tenido que rastrear la prensa periódica y la correspondencia institucional buscando aquellos datos que nos permitiesen recomponer el desarrollo y la actividad académica de estos centros educativos. Ante el avance de la secularización, la Iglesia hizo una apuesta decidida por la enseñanza que constituía, según la literatura pastoral de la época, el principal recurso para combatir la ignorancia religiosa. Muchos obispos coincidían en señalar que esta falta de conocimiento de la doctrina cristiana estaba en la base de los males que afligían al país y era necesario responder no solo con la palabra, sino con un programa de acción. El lema proclamando por el que fuera arzobispo de Valencia, Antolín Monescillo, de "pan y catecismo» resumía muy bien el programa de la acción social católica. Era necesario promover mejoras económicas que facilitaran a los obreros el sustento cotidiano, pero, junto a la economía, la educación era considerada como algo esencial para conseguir el progreso de la sociedad. Así lo defendían los obispos que rigieron la diócesis de Zamora durante los últimos años del siglo XIX, cuyo magisterio pastoral analizaremos en el primer apartado de este artículo. Como afirmaba hace dos décadas José Andrés Gallego, «el catolicismo social tuvo una parte activa y otra teórica; una labor de redención práctica y otra de elaboración doctrinal» ${ }^{8}$. En el primer apartado presentaremos la elaboración teórica de este proyecto de acción social y educativa y en los dos restantes analizaremos las iniciativas que surgieron desde este planteamiento: las Escuelas Nocturnas y Dominicales dedicadas a la instrucción de las clases trabajadoras y el Círculo Católico de Obreros que continuó la actividad de las escuelas precedentes, pero integrando en su proyecto otras dimensiones más acordes con los nuevos tiempos.

Andrés-Gallego, José: Pensamiento y acción social de la Iglesia en España, Madrid, Espasa, 1984 .

6 Escudero Imbert, José: «Conversación en Pamplona con Yves-Marie Hilaire», Anuario de Historia de la Iglesia, 7 (1998), p. 31I; Callahan, William J.: La Iglesia católica en España (I875-2002), Barcelona, Crítica, 2002, p. 197.

Montero, Feliciano: El primer catolicismo social y la Rerum novarum en España (I889-I902), Madrid, Consejo Superior de Investigaciones Científicas, I983, p. 88. Retomando este mismo lema, el obispo de Zamora Tomás Belestá reclamaba en el Senado «pan y hojas de catecismos» como remedio para la situación de España: Diario de las Sesiones de Cortes: Senado, I33, 3 de marzo de 1892, p. 228r.

Andrés Gallego, José: «La acción social y educadora de la Iglesia en ámbitos especiales y de marginación», en BARTOLOMÉ MARTínez, Bernabé: Historia de la acción educadora de la Iglesia en España, tomo II, Edad Contemporánea, Madrid, Biblioteca de Autores Cristianos, 1997, p. 836. 
«EDUCAR CRISTIANAMENTE A LOS OBREROS». ACTIVIDAD EDUCATIVA EN LA DIÓCESIS DE ZAMORA DURANTE LA RESTAURACIÓN: LAS ESCUELAS DE ADULTOS... MIGUEL-ÁNGEL HERNÁNDEZ FUENTES

\section{La educación religiosa como remedio para todos los males}

Muchos obispos estaban convencidos de que la mayor parte de los males que aquejaban a la sociedad tenían una base religiosa y procedían de la ignorancia de la doctrina y la moral cristiana o, al menos, esto se desprende de una lectura atenta de muchas de sus pastorales y discursos. Así se expresaba el obispo de Zamora Tomás Belestá Cambeses, que rigió los destinos de la diócesis entre I88I y I893, en una circular por la que ordenaba la explicación de la doctrina cristiana en todas las iglesias de la diócesis: «Bien sabéis que los males que aquejan a los

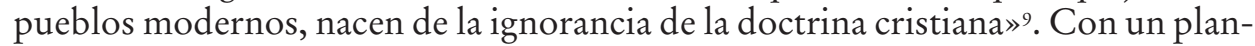
teamiento un tanto intelectualista de la moralidad, los prelados confiaban en la instrucción cristiana como la solución para la mayor parte de los problemas que asolaban España y en esto coincidían parcialmente con los regeneracionistas. Estos veían necesaria una reforma de la educación para el progreso del país, aunque no coincidían con la Iglesia en el carácter religioso de esta instrucción. En este sentido, el obispo de Zamora señalaba ante el Senado que no había más que un camino para la regeneración de la sociedad: «educar cristiana y religiosamente» ${ }^{\mathrm{I}}$.

Como ha señalado Cristóbal Robles Muñoz, entre los obispos existía «una conciencia compartida sobre el papel estratégico que tenía la enseñanza como factor moralizador y como elemento de cohesión para conservar las creencias y las normas católicas» ${ }^{\mathrm{II}}$. Moralizar quería decir instruir y, según este principio, la enseñanza era el factor básico de reforma social, lo que hacía de la formación religiosa y moral del pueblo una de las principales preocupaciones de la Iglesia. En sus cartas pastorales, el ya mencionado obispo monseñor Belestá insistía en la necesidad de elevar el nivel de instrucción cristiana del pueblo como camino para mejorar su conducta en la sociedad ${ }^{12}$. Y para la consecución de este objetivo, el prelado zamorano reclamaba la cooperación de las autoridades públicas: «Es indispensable que los gobiernos procuren por los medios que las leyes ponen a su alcance, fomentar esa instrucción que hoy se encuentra olvidada y completamente abandonada» ${ }^{13}$. Extender la enseñanza del Catecismo y mantener la presencia de la religión en los Institutos y en las Escuelas Normales eran algunas de las reivindicaciones constantes en sus escritos, pues, como ha señalado Leoncio Vega Gil, la cuestión escolar estaba en el centro de la preocupación de la Iglesia ${ }^{14}$.

En este sentido, Tomás Belestá deseaba la creación de unas escuelas destinadas a la formación religiosa de las clases populares; un tema que él mismo llevó

9 Belestá Cambeses, Tomás: «Instrucción pastoral», BEOZA, I9 (I88I), p. 3I3.

io Diario de las Sesiones de Cortes: Senado, I33, 3 de marzo de i892, p. 228I.

" Robles Muñoz, Cristóbal: «La diócesis de Cartagena durante la Restauración (I875-1900)», Murgetana, 79 (1989), p. I03.

I2 Belestá Cambeses, Tomás: «Carta pastoral sobre la necesidad de instrucción cristiana al acercarse la santa Cuaresma», BEOZA, 26 (I888), pp. 69-70.

${ }_{13}$ Diario de las Sesiones de Cortes: Senado, 133, 3 de marzo de I892, p. 228I.

${ }^{14}$ Vega Gil, Leoncio: «Las fundaciones benéfico-docentes y la educación y formación del obrero en España (I899-I972)», Historia de la Educación, I8 (I999), p. I6I. 


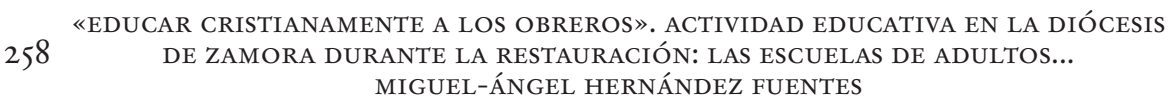

al Senado con motivo del debate sobre la ley del descanso dominical. El prelado zamorano reclamaba ante la Cámara Alta la necesidad de liberar el domingo de cualquier compromiso laboral para que los trabajadores pudieran descansar, cumplir con los preceptos religiosos y mejorar su educación ${ }^{15}$. Por su carácter festivo, el domingo era el día elegido en muchas poblaciones para el funcionamiento de las Escuelas Dominicales con las que se pretendía paliar las deficiencias educativas de los obreros. En los debates parlamentarios los obispos se centraban en la dimensión religiosa del precepto dominical, y es lógico, pues ellos mismos habían defendido que su presencia en el Senado no tenía un carácter político. Según ellos mismos afirmaban, los prelados acudían a la Cámara Alta para defender los principios religiosos y los intereses de la Iglesia ${ }^{16}$, pero tampoco olvidaban la dimensión social del descanso dominical e instaban al Estado a su cumplimiento:

La observancia de los días de fiesta no es solo un precepto divino, sino que también lo es de orden natural, porque no hemos de considerar al hombre como una máquina; el hombre necesita descansar siquiera un día a la semana para emprender con más fuerza los trabajos propios del oficio o profesión a que dedique ${ }^{17}$.

Esta dimensión social del domingo defendida por el obispo habría que entenderla en el mismo sentido del papa León XIII, como una necesidad humana frente a la explotación capitalista del trabajador, sometido en algunas tareas profesionales a jornadas de trabajo interminables y a duras condiciones físicas ${ }^{18}$.

En línea con su predecesor, el obispo Luis Felipe Ortiz, que estuvo al frente de la diócesis de Zamora entre i893 y I9I4, creía que el desconocimiento de la doctrina cristiana era la «causa primordial del pecado y de la apostasía» ${ }^{19}$. Según este prelado, la ignorancia religiosa no era solo un obstáculo para el crecimiento de la fe, sino un perjuicio para la sociedad entera y para la Iglesia ${ }^{20} y$, por ello, animaba a sus diocesanos a cultivar la formación religiosa y la lectura de la buena prensa y les presentaba la educación como el remedio para evitar «el decaimiento de las costumbres y el predominio de los vicios $»^{21}$. La enseñanza que promovía la Iglesia tenía, por tanto, un fin bien preciso: la moralización de la sociedad y el sostenimiento de la fe. Esto debía perseguirse mediante la instrucción y la alfabetización de la masa social como un peldaño para conseguir la reforma de las costumbres.

15 Según el obispo, los jornaleros precisaban «unos días de descanso para pensar en sí, para que vayan a la Iglesia, para que lean libros que puedan ilustrarles en el sentido católico, para que oren y mediten, y a fin de que tengan también todas las distracciones que todos necesitamos», Diario de las Sesiones de Cortes: Senado, 59, 3 de junio de r891, p. 903.

16 Belestá, Tomás: «A los electores de la provincia de Zamora», BEOZA, 29 (I89I), p. 70.

${ }_{17}$ Diario de las sesiones de Cortes: Senado, 191, 20 de junio de I890, p. 3752.

18 Rerum novarum, n. 3 I.

19 Ortiz Gutiérrez, Luis Felipe: «Circular al clero sobre el tiempo de la Santa Cuaresma», BEOZA, 32 (1894), p. 36.

${ }_{20}$ Idem: "Carta pastoral exponiendo los males de la época presente y exhortando a los fieles de Zamora a recibir a los padres llamados a dar misiones en la diócesis», BEOZA, 34 (I896), pp. I y ss.

${ }_{21}$ Ibidem, p. 22. 
«EDUCAR CRISTIANAMENTE A LOS OBREROS». ACTIVIDAD EDUCATIVA EN LA DIÓCESIS DE ZAMORA DURANTE LA RESTAURACIÓN: LAS ESCUELAS DE ADULTOS... MIGUEL-ÁNGEL HERNÁNDEZ FUENTES

Los congresos nacionales, las misiones populares o la enseñanza del catecismo fueron algunas de las iniciativas que se proponían para combatir esta falta de formación y levantar «diques contra la invasión creciente del blasfemo y corruptor naturalismo moderno $»^{22}$ como indicaba el obispo en una circular.

Algunos han criticado el proyecto educativo eclesial por estar muy condicionado por el propósito de adoctrinar a las clases trabajadoras ${ }^{23}$, sin embargo, en este asunto los católicos no hacían nada diferente a otros colectivos. Como ha señalado Tiana Ferrer, la educación obrera siempre estuvo cargada de una importante significación ideológica y cada uno de los grupos «pretendía plasmar en su actuación sus principios teóricos, doctrinales, políticos o sociales» ${ }^{24}$. La instrucción social no era un campo neutro de acción, sino un espacio apetecido por las diversas instancias sociales que veían en la masa obrera un colectivo al que orientar educativamente conforme a sus propios intereses. Entre todos estos colectivos, José Estarán Molinero ha afirmado que los católicos sociales fueron, posiblemente, quienes más contribuyeron a la expansión de la educación popu$\operatorname{lar}^{25}$. En sus centros se promovía la instrucción como un camino privilegiado para abandonar el analfabetismo religioso y, junto a este propósito, también se elevó el nivel educativo de la clase obrera mediante la docencia de algunas enseñanzas técnicas y los rudimentos de la lectura, la escritura y el cálculo.

Con este deseo de promover la educación católica de las masas, se impulsaron en la diócesis de Zamora diversas instituciones dedicadas a mejorar la instrucción de los feligreses, lo que trajo consigo la creación de numerosas propuestas educativas que se desplegaron a lo largo de la segunda mitad del siglo xIx. Se organizó la catequesis, se trató de mejorar la predicación, se luchó por el mantenimiento del catecismo en la escuela, se fundaron congregaciones religiosas dedicadas a la educación y se crearon escuelas para la formación de los trabajadores. Estas últimas no eran, por tanto, una simple apuesta por la alfabetización, sino que la educación social impulsada por la Iglesia nacía del deseo de mantener a los trabajadores dentro de la comunidad cristiana. Esta era la misión que debía guiar a los pastores de la diócesis y el propósito último de la misión de la Iglesia: la evangelización. En este empeño, los obispos estaban convencidos de que la mejora del nivel de la instrucción religiosa de los católicos era el camino principal para resistir al secularismo y así lo confesaban por escrito en numerosas ocasiones: «Este mortal

${ }^{22}$ "Circular dando cuenta de haberse constituido en la diócesis la junta diocesana para el fomento en esta diócesis del Congreso Católico Nacional y excitando a sus diocesanos a tomar parte en esta asamblea», BOOZA, 37 (I899), pp. I6I-I64.

${ }_{23}$ Así se ha expresado, por ejemplo, Leoncio Vega Gil al señalar que el programa educativo iniciado a finales del siglo xix por parte del catolicismo social no pretendía «objetivos económicos o técnicos sino ideológicos, políticos y un amplio deseo de protagonismo social», VEGA GIL, Leoncio: «Las fundaciones benéfico-docentes y la educación y formación del obrero en España (I899-1972)», Historia de la Educación, I8 (1999), p. I66.

24 Tiana Ferrer, Alejandro: Maestros, misioneros y militantes. La educación de la clase obrera madrileña, I898-I9I7, Madrid, Ministerio de Educación y Ciencia, I992, p. 427.

25 Estarán Molinero, José: «Aportación del catolicismo social en Aragón a la educación popular (1857-1923)», Participación Educativa, número extraordinario (2010), pp. 91-107. 


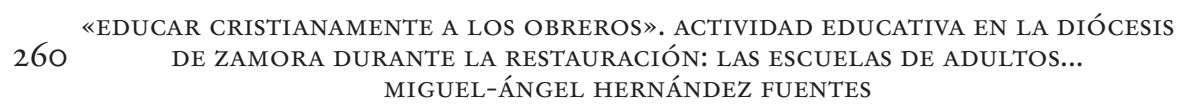

descuido y humillante ignorancia de la doctrina cristiana está siendo a la vez la causa y efecto de la indiferencia religiosa y de la atonía de la conciencia ${ }^{26}$. En este proyecto eclesial hemos de enmarcar la actividad de las Escuelas de Adultos que constituyeron uno de los primeros pasos de la acción social católica en Zamora y que fueron promovidas con anterioridad a la encíclica Rerum novarum.

\section{Implantación y desarrollo de las Escuelas Dominicales y Nocturnas}

La existencia de unas Escuelas Dominicales o Nocturnas, dedicadas a la instrucción de los trabajadores fuera de su horario laboral, hunde sus raíces en la Italia del siglo $\mathrm{XVI}^{27}$, aunque su implantación en España se hizo efectiva en el siglo XIX. Según la Ley de Instrucción Pública de 1857, las autoridades debían fomentar el establecimiento de estos centros educativos en todas las capitales y localidades mayores de diez mil habitantes ${ }^{28}$. Sin embargo, su puesta en marcha no siempre fue potenciada por los municipios que debían invertir en ellas notables recursos. Con una cierta prioridad cronológica a esta disposición legal, se constituyó en Madrid la Real Asociación de Escuelas Dominicales cuyo primer centro abrió las puertas el I9 de marzo de I857 bajo el patronazgo de san José. Detrás de esta fundación estaban el jesuita Mariano Cortés y la condesa de Humanes, que fue su presidenta hasta I865 en que falleció. El I2 de septiembre, dos días después de ser publicada la ley de instrucción antes citada, el Gobierno aprobó los estatutos de las Escuelas Dominicales fundadas por el padre Mariano Cortés y su correspondiente reglamento. Esto supuso un importante respaldo legal a su actividad y, treinta años después de fundadas, habían pasado por sus aulas más de cincuenta mil alumnas, contando las escolarizadas tan solo en Madrid ${ }^{29}$. Sin embargo, la actividad de estas escuelas no quedó circunscrita a la capital de España. Entre i857 y 1868 las escuelas se extendieron por otras provincias, arraigando en muchas de las poblaciones españolas más importantes ${ }^{30}$. Su rápida implantación por la geografía peninsular motivó la publicación de un breve del papa Pío IX, fechado el Is de abril de 1864 , por el que ensalzaba su actividad y concedía indulgencias a sus

26 Ortiz Gutiérrez, Luis Felipe: «Enseñanza de doctrina cristiana», Boletín Oficial del Obispado de Zamora (en adelante BOOZA), 2I (I906), p. 293.

27 Puebla, Agustín: «Sobre las escuelas de adultos», Boletín-Revista de la Universidad de Madrid, 2 (I870), pp. I499-I5I4, I599-16I2 y I699-I7I2.

${ }_{28}$ «Art. Io6. Igualmente fomentará el establecimiento de lecciones de noche o de domingo para los adultos cuya instrucción haya sido descuidada, o que quieran adelantar en conocimientos. Art. I07. En los pueblos que lleguen a Io.ooo almas habrá precisamente una de estas enseñanzas, y además una clase de Dibujo Lineal y de Adorno, con aplicación a las Artes Mecánicas», Ministerio de FoMENTo: «Ley de Instrucción Pública», Gaceta de Madrid, io de septiembre de i857, p. 2.

29 Fernández Loredo, Juan: «Origen, desenvolvimiento, beneficios y estado actual de las escuelas católicas, dominicales y catequísticas», en Crónica del Primer Congreso Católico Nacional Español, Madrid, Tipografía de los Huérfanos, i889, pp. 383-392.

30 Andrés-Gallego, José: La Iglesia en la España contemporánea, tomo i, 1800-1936, Madrid, Ediciones Encuentro, 1999, p. 22I. 
«EDUCAR CRISTIANAMENTE A LOS OBREROS». ACTIVIDAD EDUCATIVA EN LA DIÓCESIS DE ZAMORA DURANTE LA RESTAURACIÓN: LAS ESCUELAS DE ADULTOS... MIGUEL-ÁNGEL HERNÁNDEZ FUENTES

participantes. La finalidad de este proyecto educativo católico era la de instruir a las jóvenes y sirvientas entre doce y treinta años que no pudiesen asistir a los centros de enseñanza diurna y, con ello, lograr su promoción social mediante la formación cultural y el estudio de las primeras letras, las reglas aritméticas y de algunas enseñanzas técnicas elementales.

No tenemos mucha información acerca de la actividad desarrollada por estas escuelas en Zamora con anterioridad al Sexenio Democrático. Sabemos que bajo el pastoreo del obispo Bernardo Conde y Corral iniciaron su andadura en torno a i865 bajo la dirección de las Conferencias de San Vicente de Paúl. En ellas se enseñaba a leer y escribir, se impartía la doctrina cristiana y se instruía a las mujeres a llevar una vida honesta ${ }^{31}$. Se trataba de una escuela orientada a la alfabetización elemental y a la instrucción religiosa y moral. Sin embargo, este centro debió extinguirse tras el estallido de la Revolución Gloriosa, borrándose entonces todo rastro documental.

Con la llegada de la Restauración, las Escuelas de Adultos abrieron de nuevo sus puertas, aunque esta vez no lo hicieron bajo la tutela del Obispado, sino que fueron una propuesta municipal destinada a todos los obreros de la ciudad. Según un artículo publicado en el semanario El Eco del Duero, estas escuelas fueron inauguradas el 26 de octubre de 1878 por el gobernador civil de la provincia Francisco del Villar ${ }^{32}$. La oferta tuvo una excelente acogida y, según el periódico El Amigo de los Maestros, el número de matriculados ascendía inicialmente a seiscientos dieciséis trabajadores de diversos oficios y edades. Los profesores eran miembros del claustro de la Normal y de otros centros educativos, con quienes los obreros aprendían los rudimentos del Dibujo, la Aritmética y la Geometría. Los interesados recibían sus clases en el Instituto Provincial y en otras cuatro escuelas de la ciudad que hubieron de habilitarse por un abultado número de alumnos que desbordó las previsiones. Sin embargo, este proyecto, tan exitoso en sus orígenes ${ }^{33}$, fracasó pronto por la desidia o por la apatía de alumnos y profesores, descendiendo la matrícula a tan solo cincuenta estudiantes activos tres meses después de su inauguración. El Eco del Duero recogía esta deserción de los obreros $\mathrm{y}$, desde sus páginas, se les invitaba a participar en las clases como remedio ante la ociosidad y prevención frente a los peligros de una vida callejera, cuyos efectos

${ }_{31}$ Archivo Histórico Diocesano de Zamora (en adelante AHDZA), Secretaría de Cámara, legajo 34/21, Visita ad limina hecha por Bernardo Conde y Corral, 1866.

32 «Las escuelas de obreros en Zamora», El Eco del Duero, i8 de enero de I879, p. I. Este artículo fue presentado en su día por uno de los mayores estudiosos de la historia de la educación en Zamora: Vega Gil, Leoncio: «Educación y sociedad en Zamora», en Mateos Rodríguez, Miguel Ángel (coord.): Historia de Zamora, tomo III, La historia contemporánea, Zamora, Instituto de Estudios Zamoranos «Florián de Ocampo», 1995, p. 258.

33 El eco de esta noticia traspasó el ámbito local, apareciendo en El Magisterio Español, órgano general de los establecimientos de enseñanza y defensor de los intereses y derechos de los catedráticos y maestros: «En el instituto de Zamora se han establecido algunas cátedras gratuitas donde por la noche puedan adquirir los obreros los conocimientos necesarios para sus respectivos artes y oficios. Ya pasa de cuatrocientos el número de matriculados», El Magisterio Español, 5 de diciembre de 1878 , p. 4. 


\section{«EDUCAR CRISTIANAMENTE A LOS OBREROS». ACTIVIDAD EDUCATIVA EN LA DIÓCESIS 262 DE ZAMORA DURANTE LA RESTAURACIÓN: LAS ESCUELAS DE ADULTOS... MIGUEL-ÁNGEL HERNÁNDEZ FUENTES}

habrían «de lamentar durante su vida» ${ }^{34}$. Asimismo, se pedía a los profesores que superasen su apatía y que recuperasen el entusiasmo manifestado en los primeros días, pues era de esperar que aquellos trabajadores que asistían por pasatiempo desapareciesen ${ }^{35}$.

Este proyecto promovido por las instituciones públicas fue desapareciendo y perdemos su rastro poco después de haber sido fundadas. Sin embargo, con la llegada de Tomás Belestá a la sede episcopal de Zamora las escuelas volvieron a ponerse en funcionamiento, aunque impulsadas esta vez por la autoridad eclesiástica. El contacto que Belestá había tenido durante su etapa salmantina con la docencia le hizo especialmente sensible a estos proyectos educativos que él mismo había alentado mientras era rector de la Universidad ${ }^{36}$. El obispo estaba convencido de la existencia de notables deficiencias educativas en las capas inferiores de la sociedad y deseaba hacerles frente mediante la apertura de unos centros educativos compatibles con el horario laboral. Con este propósito, durante el invierno de I883-I884, se establecieron unas Escuelas Nocturnas dedicadas a la formación de los obreros y otras Dominicales orientadas a la educación de las mujeres. En ellas no solo se enseñaría el catecismo, sino que se impartirían aquellas asignaturas necesarias para mejorar la situación de los obreros: Lectura, Escritura, Aritmética o Gramática. Este deseo de elevar el nivel de la educación popular estaba íntimamente unido al deseo de mejorar su instrucción religiosa y elevar su moralidad, pues, como señalaba el prelado, la adquisición de los conocimientos indispensables para la vida ayudaría a los obreros a sostener su moralidad y religiosidad ${ }^{37}$ :

La instrucción religiosa para moralizar y poner al alcance de las jóvenes alumnas las obligaciones que como católicas tienen, apartándolas del vicio, haciendo conocer sus horribles estragos y la hermosura y bellezas de la virtud inspirándolas

34 «Las escuelas de obreros...», p. I.

35 Idem.

36 Tomás Belestá fue rector de la Universidad de Salamanca durante el curso 1853/54 y entre 1858 y 1865. Entre las actividades desarrolladas durante su rectorado podemos contar el impulso que dio a la organización de los Institutos de Segunda Enseñanza, de las Escuelas Normales de Maestros y apoyó el establecimiento de las Escuelas de Adultos y de la Escuela de Sordomudos y Ciegos. Para promover la formación de adultos, propuso al Gobierno que estas escuelas tuviesen alguna gratificación, por pequeña que fuese, y que se declarasen obligatorias en todas las provincias para que así «pudiera presentarse coyuntura favorable a los que concurrieran a ellas, de fijar de una manera duradera y estable los conocimientos que adquirieran en su primera edad, o conseguir alguna instrucción, los que desgraciadamente no asistieron en la misma a las escuelas de sus respectivas localidades", «Escuela de adultos», en Memoria acerca del estado de la enseñanza en la Universidad Literaria de Salamanca y establecimientos de instrucción pública del distrito en el curso de I86I a I862, y anuario de la misma de I862 a I863, Salamanca, Imprenta de Diego Vázquez, I863, p. 69. Sobre este asunto: Hernández Fuentes, Miguel Ángel: La diócesis de Zamora durante la Restauración. El pontificado del obispo Tomás Belestá y Cambeses (I881-19I4), Trabajo de grado, Universidad de Salamanca, 2012.

37 No se pueden separar estas dos pretensiones. Ya Leoncio Vega Gil señalaba en i999 que las iniciativas educativas promovidas por la Iglesia en relación con la educación de las clases trabajadoras pretendían «la moralización o recristianización de la sociedad a través de la clase obrera», VEGA GIL, Leoncio: «Las fundaciones benéfico-docentes...», p. I66. 
«EDUCAR CRISTIANAMENTE A LOS OBREROS». ACTIVIDAD EDUCATIVA EN LA DIÓCESIS DE ZAMORA DURANTE LA RESTAURACIÓN: LAS ESCUELAS DE ADULTOS... MIGUEL-ÁNGEL HERNÁNDEZ FUENTES

para ello amor al trabajo y la conveniencia de saber leer y escribir que tanto pueden contribuir a evitar una peligrosa ociosidad ${ }^{38}$.

Como puede verse, las escuelas tenían una función profiláctica frente a los peligros de la calle que amenazaban a las clases populares. Según el obispo de Zamora, la enseñanza impartida en sus aulas trataba de convertirse en una alternativa frente los malos hábitos sociales que provocaba la ociosidad y, al mismo tiempo, pretendía facilitar unas relaciones sociales saludables, que alejasen a los obreros de los malos hábitos. Este planteamiento de la Iglesia coincidía con el de otros agentes sociales y económicos que habían promovido estas escuelas en años precedentes y así lo expresaba uno de los redactores de El Eco del Duero con motivo del fracaso de este proyecto municipal al que nos hemos referido anteriormente:

Es indudable que algunos obreros jóvenes, después de un día de trabajo rudo, prefieren permanecer en las esquinas de las calles, aunque haga mal tiempo, que permanecer en la taberna; no es menos cierto que muchos obreros casados, que tienen una dilatada familia, cobijada tal vez en una sola o a lo sumo en dos habitaciones, no disponen de medio alguno para disfrutar de las relaciones sociales tan deseadas por la clase media, a no ser que vayan a la taberna, en donde la ventaja de estar en sociedad se paga bebiendo. Esta es la razón porque en los obreros se observan tan peligrosas costumbres, que los conducen necesariamente a la intemperancia y la pobreza y la causa también de que los hijos de esas familias estén tan descuidados. Con la creación de estas Escuelas de Adultos en cada localidad se arrancan muchos individuos a la perdición, acaso al crimen, y se evitan muchos males ${ }^{39}$.

Las Escuelas para Adultos eran, por tanto, unos establecimientos benéficos dedicados a «la educación moral, religiosa y literaria del pueblo» ${ }^{40} \mathrm{o}$, como se anunciaba en el Boletín Oficial del Obispado de Zamora, de «un centro de moralidad y de educación» ${ }^{41}$. Así lo expresaba el propio obispo en una carta dirigida al Ayuntamiento, en la que solicitaba su colaboración para la puesta en marcha de este proyecto:

La necesidad de que el pueblo tenga la educación indispensable, siquiera ya en los primeros rudimentos de doctrina cristiana, de lectura, escritura, algunas nociones de aritmética, sistema métrico decimal y gramática castellana, nos han hecho concebir el pensamiento de plantear en esta capital, y en el próximo invierno, una Escuela de Adultos que, a la vez sirva para sostener la moral religiosa y social, sirva también para que las personas que carecen de los conocimientos arriba expresados puedan adquirirlos con ventajas. Hemos propuesto plantear igualmente en los domingos otra escuela para que las jóvenes que han tenido descuidado este banco de

«Apertura de la Escuela de Adultos», BEOZA, 22 (I884), pp. 346-347.

«Las escuelas de obreros en Zamora», El Eco del Duero, i8 de enero de i879, p. I.

BEOZA, 22 (I884), pp. 38-39.

"Anuncio de inauguración de las Escuelas Dominicales», BEOZA, 2I (I883), pp. 348-349. 


\section{«EDUCAR CRISTIANAMENTE A LOS OBREROS». ACTIVIDAD EDUCATIVA EN LA DIÓCESIS 264 DE ZAMORA DURANTE LA RESTAURACIÓN: LAS ESCUELAS DE ADULTOS... MIGUEL-ÁNGEL HERNÁNDEZ FUENTES}

instrucción, pudieren adquirirlo en horas compatibles con las ocupaciones propias de su clase ${ }^{42}$.

El Ayuntamiento respondió afirmativamente a la propuesta episcopal, facilitando los locales y costeando el menaje y los demás utensilios necesarios para su funcionamiento ${ }^{43}$. Tan solo una cuestión quedó en el tintero de la propuesta episcopal. En aquella misiva, monseñor Belestá solicitaba a la corporación municipal que los maestros de las escuelas públicas se encargasen de la docencia, pero el Consistorio respondió que ya invertían seis horas diarias y que, por tanto, no era posible dedicarse durante la noche a los ejercicios de la enseñanza «sin privarse en absoluto del tiempo que naturalmente necesitan para descansar de sus penosas tareas» ${ }^{44}$. El obispo hubo de buscar a los profesores por su propia cuenta, pidiendo la colaboración desinteresada de diversas personas vinculadas con el magisterio y la caridad. Para la enseñanza en la Escuela de Adultos contó con los profesores del Seminario ${ }^{45}$ que estuvieron coordinados por el director de la Escuela Normal, quien destacó por ser uno de los máximos impulsores del proyecto, quien asumió la dirección del centro durante el primer curso ${ }^{46}$. Para las Escuelas Dominicales, monseñor Belestá contó con algunas maestras de los colegios públicos de la ciudad y con algunas señoras de las Conferencias de San Vicente de Paúl47 que estaban al frente de diversas iniciativas benéficas en Zamora y que fueron pioneras en el desarrollo de una actividad sociocaritativa dirigida por seglares conforme a un modelo decimonónico. En otras ciudades como Salamanca, la atención a estos centros corrió a cargo de alguna orden religiosa que se dedicaba complementariamente a la enseñanza ${ }^{48}$, pero en Zamora la falta de congregaciones masculinas y la escasez de femeninas dificultaba la encomienda de estas tareas educativas a las religiosas. El obispo hubo de buscar, por tanto, el apoyo del personal seglar y de los

42 «Carta del obispo de Zamora, Tomás Belestá, al Ayuntamiento de la capital» (Zamora, i6 de octubre de I883), AHDZA, Secretaría de Cámara, legajo 136/I, Libro 2. ${ }^{\circ}$ copiador de la correspondencia oficial (I872-1890), fol. 65 y AHDZA, Secretaría de Cámara, legajo 157, Carta del obispo de Zamora, Tomás Belestá, al Ayuntamiento de la capital, Zamora, 16 de octubre de 1883.

43 BEOZA, 2I (I883), pp. 348-349.

44 AHDZA, Secretaría de Cámara, legajo 157, Carta del Ayuntamiento de Zamora al obispo Tomás Belestá, Zamora, 6 de noviembre de i883. Es muy probable que tras esta negativa planease el fracaso que el proyecto educativo había tenido tan solo cinco años antes.

${ }^{45}$ El Seminario contaba con un amplio claustro de profesores que formaban parte de lo más selecto del clero zamorano: Hernández Fuentes, Miguel Ángel: «Canónigos y profesores», Cúpula, I8 (2010), pp. I4-18.

${ }^{46}$ Así lo reconocía el Obispado ante la inauguración de este centro educativo: «Vencidas todas las dificultades, gracias a la cooperación de la excelentísima Corporación municipal y al inteligente celo del señor don Juan López, director de la Escuela Normal, se ha podido llevar a efecto y realizar un establecimiento tan necesario para la educación moral, religiosa y literaria del pueblo", $B E O Z A, 22$ (I884), p. 28. El director de la Escuela Normal asumió la dirección de la Escuela de Adultos de modo desinteresado, pues como se reconocía y agradecía su labor desde las páginas del Boletín, estuvo «encargado gratuitamente de organizar y dirigir tan benéfico establecimiento», ibidem, p. I23.

47 BEOZA, 2I (I883), p. 348.

48 Esteban de Vega, Mariano: De la beneficencia a la previsión. La acción social en Salamanca (I875-1889), Salamanca, Diputación de Salamanca, 1991, p. I92. 
«EDUCAR CRISTIANAMENTE A LOS OBREROS». ACTIVIDAD EDUCATIVA EN LA DIÓCESIS DE ZAMORA DURANTE LA RESTAURACIÓN: LAS ESCUELAS DE ADULTOS... MIGUEL-ÁNGEL HERNÁNDEZ FUENTES

sacerdotes que estaban dedicados a la enseñanza en el Seminario. Posteriormente el desarrollo y la estabilidad de las religiosas del Amor de Dios y de las Siervas de San José permitió contar con estas dos congregaciones para el sostenimiento de la enseñanza popular.

Tras las gestiones necesarias para poner todo a punto, la inauguración de las Escuelas Dominicales tuvo lugar el 8 de diciembre de i883, con un acto solemne en el que se leyeron sus normas de funcionamiento ${ }^{49}$. La Escuela de Adultos hubo de esperar unos días, pues era indispensable que antes se reparase el local cedido por el Consistorio ${ }^{50}$, comenzando su actividad a comienzos del año $1884^{5 \mathrm{I}}$. Respecto al número de obreros inscritos, la Escuela Dominical comenzó el curso con ciento cuarenta alumnas y la de Adultos con ciento diecinueve ${ }^{52}$, pero su número fue creciendo progresivamente en ambos centros hasta superar los cuatrocientos: doscientos trece en la Dominical y doscientos veinte en la Nocturna. Este incremento del alumnado mostraba la aceptación de una iniciativa en favor de la educación popular que no siempre había cuajado con éxito en la ciudad. En esta ocasión sucedía de modo inverso a lo acontecido en aquel proyecto educativo promovido por el Consistorio. En estas nuevas escuelas impulsadas por la diócesis el alumnado se iba incrementando y así lo pudo comprobar el obispo en una visita girada en enero de I884, reconociendo que, «a pesar de la extensión de la escuela», no podían ser admitidos más alumnos «por estar lleno el local»`3. Para estimular el aprendizaje, el último día del curso se entregaban diversos premios costeados por el obispo en un acto que revestía toda solemnidad y que pretendía servir de gancho para que otros trabajadores se matricularan al año siguiente ${ }^{54}$.

Pasado el verano, el i2 de octubre de i884 se inauguró un nuevo curso académico en la Escuela Dominical y, según las crónicas, también contó ese año con una gran concurrencia de señoras. El 2 de noviembre, con un redoblado esfuerzo de profesores, también comenzó su actividad la Escuela Nocturna de Adultos dirigida en esta ocasión por el regente de la Escuela Normal, Agapito Hernández, quien estaba auxiliado por dos facultativos retribuidos por el Ayuntamiento ${ }^{55}$ y

49 «Inauguración de una escuela dominical en esta ciudad», BEOZA, 2I (I883), pp. 36I-362.

so Ahdza, Secretaría de Cámara, legajo 157, Carta del Ayuntamiento de Zamora al obispo Tomás Belestá, Zamora, ıo de diciembre de I883.

${ }_{51}$ «Inauguración de una escuela nocturna», BEOZA, 22 (I884), p. 28.

$52 \quad B E O Z A, 2 \mathrm{I}(\mathrm{I} 883)$ ), p. 36I y BEOZA, 22 (I884), p. 29.

53 «Visita del obispo a las escuelas», BEOZA, 22 (I884), pp. 38-39.

54 El primer año de funcionamiento de la Escuela de Adultos se entregaron los premios en el mes de marzo de i884 a sesenta y seis alumnos. Ese día, tras los discursos oficiales, uno de los premiados intervino para animar a sus compañeros a continuar sus estudios para el curso siguiente: $B E O Z A$, 22 (1884), pp. I23-I24. En la Escuela Dominical, al concluir el curso 1885/86, recibieron el premio ochenta alumnas que se habían distinguido por la asistencia al centro, la aplicación y los resultados. Estos premios consistían en unos pañuelos de seda costeados por el propio obispo y unos libros del Corazón de Jesús entregados por las señoras de la Conferencia de San Vicente de Paúl: BEOZA, 24 (I886), pp. 219-220.

"El Ayuntamiento «auxiliará en el próximo curso, como lo hizo en el año anterior, al establecimiento de la enseñanza de adultos, facilitando al efecto el material necesario y [...] retribuirá con la cantidad de dos pesetas diarias a los dos auxiliares y facultativos que coadyuven durante la 


\section{«EDUCAR CRISTIANAMENTE A LOS OBREROS». ACTIVIDAD EDUCATIVA EN LA DIÓCESIS 266 DE ZAMORA DURANTE LA RESTAURACIÓN: LAS ESCUELAS DE ADULTOS... MIGUEL-ÁNGEL HERNÁNDEZ FUENTES}

por varios eclesiásticos que colaboraban gratuitamente ${ }^{56}$. Este curso comenzó con ciento cuarenta alumnos y, del mismo modo que ocurrió el año precedente, su número se fue incrementando57. En 1885, al comenzar el nuevo curso, el obispo solicitó una vez más la colaboración económica del Consistorio, pero éste le respondió que ya no podía hacerse cargo de los gastos, poniendo tan solo a disposición del prelado el local de los Descalzos. Las razones aducidas por el Consistorio eran económicas y así se lo exponían al obispo.

Con profunda pena se ve el Ayuntamiento que tengo la honra de presidir en la necesidad de suprimir los gastos que el sostenimiento de la Escuela Nocturna de Adultos exige. El considerable aumento que en el presupuesto de Instrucción Primaria ha ocasionado la nivelación de los sueldos de las maestras con el de los maestros de las escuelas públicas, que eleva el crédito consignado para este servicio a 24.856 pesetas, las mermas que en los ingresos municipales ha producido la novísima ley de consumos, merma que representa más de 75.000 pesetas anuales y la circunstancia de haber tenido el Ayuntamiento que hacer frente a los excesivos gastos que se han originado con motivo de la epidemia colérica, afortunadamente combatida con la ayuda de Dios y mediante los sacrificios pecuniarios que sin limitación ha sido preciso hacer, han tenido a esta corporación municipal en una situación financiera tan apurada que, apenas si podrá introducir todas sus economías que, una buena administración corriente atiende, [...] sin perjuicio de que, caso de establecerse la Escuela de Adultos, el Ayuntamiento ponga a disposición del director de la misma el local de la pública de los descalzos y los libros existentes en poder del mismo desde el año anterior ${ }^{58}$.

Ante esta negativa del Ayuntamiento, el obispo asumió los gastos generados por la Escuela ${ }^{59}$ y la docencia continuó del mismo modo durante el curso I886/1887 ${ }^{60}$. En I887, con el acuerdo de la Conferencia de San Vicente de Paúl, las Escuelas Dominicales se trasladaron al Colegio del Amor de Dios, cuyas religiosas se prestaron a colaborar con esta actividad educativa ${ }^{6}$. Precisamente estas religiosas fundadas en Toro se habían establecido en la ciudad en I884 y tenían como

temporada», AHDZA, Secretaría de Cámara, legajo 157, Carta del Ayuntamiento de Zamora al obispo Tomás Belestá, Zamora, 20 de septiembre de I884.

56 "Apertura de la Escuela de Adultos», BEOZA, 22 (I884), p. 346.

57 Ibidem. De esta iniciativa educativa se hizo eco la prensa especializada en El Magisterio Español dando el periódico la enhorabuena por el esfuerzo realizado en la ciudad «en favor de la enseñanza popular», El Magisterio Español, io de noviembre de i884, p. 3; idem, is de noviembre de I884, p. 4 .

${ }_{58}$ AHDZA, Secretaría de Cámara, legajo 157, Carta del Ayuntamiento al obispo de Zamora, Zamora, 27 de octubre de 1885 .

59 Así se le reconocía en el Boletín Oficial del Obispado tras su fallecimiento: «Fundó las escuelas dominicales y de adultos que financió durante varios años», «Don Tomás Belestá y Cambeses», $B E O Z A, 30$ (I892), p. I3O.

60 BEOZA, 24 (1886), p. 315.

${ }_{61} \quad B E O Z A, 25$ (I887), pp. 367-368. Al año siguiente, el domingo I4 del mes de noviembre se inauguró «en el colegio Amor de Dios la Escuela Dominical de Mujeres en la forma que en años anteriores; las religiosas y varias señoras y señoritas de la población se encargan de la enseñanza»: BEOZA, 26 (I888), p. 329 . 
«EDUCAR CRISTIANAMENTE A LOS OBREROS». ACTIVIDAD EDUCATIVA EN LA DIÓCESIS DE ZAMORA DURANTE LA RESTAURACIÓN: LAS ESCUELAS DE ADULTOS... MIGUEL-ÁNGEL HERNÁNDEZ FUENTES

carisma principal la educación de la mujer. Gracias a ellas, el obispo pudo contar con unas religiosas para desarrollar su proyecto de formación de la mujer trabajadora. Unos años después, al comenzar el siglo xx, el obispo Luis Felipe Ortiz encomendó a esta congregación la enseñanza no solo de las mujeres, sino también de las niñas. Por aquellas fechas las religiosas del Amor de Dios necesitaban un nuevo edificio que se adaptase a las necesidades crecientes de una congregación que estaba en expansión. El edificio que habían ocupado durante su primera estancia en Zamora había sido demolido en I89ı, tras la salida de las religiosas, y en su lugar se construyó una nueva casa propiedad de Emiliano Tabarés ${ }^{62}$. En 1902, el obispo compró esa vivienda y en 1903 se la cedió a las hermanas del Amor de Dios con la obligación de establecer en el colegio una clase diaria gratuita para niñas pobres y una Escuela Dominical para jóvenes y adultas que se mantuvo activa, al menos, hasta la llegada de la República ${ }^{63}$.

No tenemos muchas más noticias acerca del funcionamiento de estas escuelas y apenas existen algunas referencias documentales ${ }^{64}$. Sabemos algo sobre el alumnado, sobre quiénes fueron sus profesores, dónde se instalaron y qué materias se enseñaron, pero desconocemos, por ahora, el programa académico concreto, no sabemos qué ocurría en sus aulas y qué resultados tenía en los obreros. Quizá algún día podamos llenar esta laguna con el hallazgo de los libros de actas, de algún cuaderno personal o de otras fuentes documentales que desvelen las entrañas de estas escuelas. Por ahora, hemos de conformarnos con dejar constancia de su existencia y señalar que también los trabajadores fueron destinatarios de una actividad concreta e incipiente por parte de la Iglesia que tenía un carácter pedagógico, pero cuyo destino último era la formación católica. A partir de i89i, tras la fundación del Círculo Católico de Obreros de Zamora, la actividad educativa de las Escuelas Nocturnas fue asumida por este centro obrero que pasó a coordinar gran parte de la acción social de la diócesis, especialmente tras la publicación de la encíclica Rerum novarum, que traía un nuevo modelo de presencia católica en el terreno socioeconómico. No obstante, conviene señalar aquí que las Escuelas para Adultos implantadas en la ciudad han de considerarse como una de las iniciativas más tempranas de la acción social de la Iglesia de Zamora,

62 Instituto del Amor de Dios: Anales, Zamora, Imprenta «El Correo de Zamora», I937, p. I59.

${ }_{63}$ En su primera visita al Cabildo de párrocos de la ciudad de Zamora, celebrada el 3i de julio de 1929, el obispo Manuel Arce Ochotorena manifestó deseos de que hubiera una «escuela dominical capaz de poder admitir a todas las jóvenes dedicadas al servicio doméstico en la ciudad», a lo que los párrocos «le respondieron que ya estaba establecida en el Colegio Amor de Dios y dirigida por las hermanas de este instituto con asistencia del capellán», AHDZA, Parroquiales, Parroquia 28I.I4, libro 43, Libro de acuerdos y elecciones del Cabildo parroquial (I718-1940), fol. 236. Los locales no debían ser suficientemente grandes, por lo que se indicaron otros más amplios, pero todos convinieron «que estas escuelas debían estar siempre en casas de religiosas y dirigidas por ellas», idem.

${ }_{64}$ El obispo Luis Felipe Ortiz da noticia del funcionamiento de las Escuelas Dominicales y de Adultos en 1895 y en 1907 con motivo de sus visitas ad limina a la sede de Pedro. En la de I895 se congratulaba de los frutos obtenidos por estas escuelas: AHDZA, Secretaría de Cámara, legajo 34/26, párrafo 15 . En la de 1907 da noticia de su actividad junto a otras iniciativas para las que contaban con la colaboración de las Conferencias de San Vicente de Paúl: AHDza, Secretaría de Cámara, legajo 34/25, párrafo i6. 


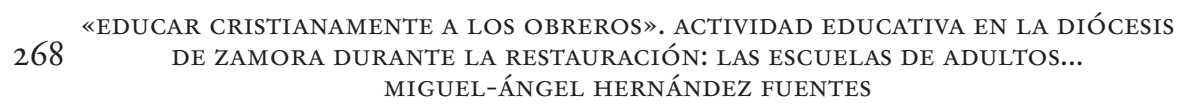

anterior incluso a la desarrollada en algunas diócesis vecinas ${ }^{65}$, e incluirla dentro de lo que posteriormente se ha denominado el «movimiento católico» ${ }^{66}$. Aquí debe insertarse esta actividad pedagógica que debe ser analizada desde sus claves y principios. La Iglesia no asumía funciones educativas neutras, ni tenía la misión de organizar la acción estatal aunque, por el carácter confesional sancionado por la Constitución de 1876, reclamase ciertas competencias. La misión de la Iglesia era promover la vida cristiana en todos los ámbitos de la sociedad y desde esta clave hemos de comprender su acción y analizar sus proyectos. La secularización de la sociedad era el antagonista de sus agentes e instituciones y el combate frente a esta secularización constituye el sentido de todas sus propuestas educativas, sociales y religiosas durante este periodo. El éxito o el fracaso de este empeño es lo que debe analizarse y no estudiar sus propuestas desde los objetivos perseguidos por otras instituciones que, desde claves ideológicas distintas, también promovieron su programa educativo propio.

\section{La actividad educativa del Círculo Católico de Obreros}

Tras su fundación en i89i, los Círculos Católicos de Obreros comenzaron a funcionar en la diócesis de Zamora el 6 de enero de i892, heredando la actividad de las Escuelas de Adultos que comenzaron en la década precedente ${ }^{67}$. Un día después de su inauguración, el 7 de enero de 1892 , ciento treinta obreros acudían a las cátedras de Primera Enseñanza, Dibujo, Música, Geografía y Matemáticas que se ofrecían en el centro y que mantuvo su actividad durante más de medio siglo. Según el Reglamento el Círculo Católico Obrero de San Martín Cid reformado en I93I, esta institución se definía como «un centro de moralidad, instrucción y recreo para sus socios protectores y obreros inscritos» ${ }^{68}$. Como puede verse, el carácter educativo y religioso estaba presente desde sus orígenes, pues asumía la actividad de las Escuelas de Adultos que antes hemos expuesto, pero incrementaba este propósito con otra finalidad de tipo recreativo y económico, tal como se refleja en sus estatutos:

El Círculo Católico, subordinándolos todos al supremo y último fin del hombre que es la mayor gloria de Dios y la salvación de las almas, persigue los siguientes

65 En Salamanca, por ejemplo, donde estas escuelas tuvieron muchísima más vitalidad que en Zamora y se extendieron a numerosos pueblos de la comarca, fueron impulsadas por el obispo Tomás Cámara a partir de una pastoral publicada en i895: Esteban de Vega, Mariano: De la beneficencia..., p. I89.

${ }_{66}$ Montero García, Feliciano: El movimiento Católico en España, Madrid, Eudema, 1993.

${ }^{67}$ «Círculo Católico de Obreros», BEOZA, 30 (1892), pp. 22-23. El Círculo fue puesto bajo el patronazgo de san Martín Cid y su primer reglamento data del año I89i, siendo reformado el 24 de enero de r918 y nuevamente el 29 de octubre de I93I: AHPZA, Gobierno Civil, Asociaciones, 9/33, Reglamento reformado del Círculo Católico San Martín Cid de la ciudad de Zamora, Zamora, 29 de octubre de 1931.

68 Ibidem, art. 2. ${ }^{\circ}$. 
«EDUCAR CRISTIANAMENTE A LOS OBREROS». ACTIVIDAD EDUCATIVA EN LA DIÓCESIS DE ZAMORA DURANTE LA RESTAURACIÓN: LAS ESCUELAS DE ADULTOS... MIGUEL-ÁNGEL HERNÁNDEZ FUENTES

fines: a) Fin religioso, o sea la conservación de la fe y moralización cristiana de todos los asociados; b) Fin instructivo, o sea la enseñanza literaria, científica y artística, basada en los principios católicos; c) Fin recreativo dirigido a proporcionar a todos los socios saludable esparcimiento y honesto recreo ${ }^{69}$.

Como puede comprobarse una vez más, el objetivo principal era la propagación de la fe y, al servicio de este propósito, estaban subordinados los demás fines. Además, para la consecución de estos objetivos se establecían diversos medios de tipo religioso, instructivo, profesional y recreativo. Los religiosos eran impulsados y coordinados por el consiliario y se centraban principalmente en la celebración de la fiesta de san Martín Cid en Zamora (30 de octubre) o del día de san José en el de Zamora y en el de Toro (is de marzo) ${ }^{70}$. Este último día tenía lugar una comunión general que servía para el cumplimiento pascual de sus asociados ${ }^{71}$. Asimismo, se encargaba de todo lo concerniente al entierro de sus socios y a la oración por los difuntos. El Círculo Católico asumía también en sus estatutos un carácter benéfico, aunque las dificultades económicas dificultaron la consecución de este objetivo ${ }^{72}$. Al principio el cumplimiento de este propósito se satisfacía con la concesión de determinados premios y ayudas económicas, pero con la llegada del nuevo siglo comenzaron a desarrollarse otras iniciativas como la creación de una Caja de Socorros Mutuos ${ }^{73}$ que comenzó a funcionar en $190 \mathrm{I}^{74}$ o la creación de algunos sindicatos profesionales de inspiración católica que comenzaron a funcionar en las primeras décadas del siglo $\mathrm{XX}^{75}$.

69 Ibidem, art. 5. .

70 Véase por ejemplo el «Homenaje del Círculo Católico de Obreros de Zamora a san José», BOOZA, 55 (1917), pp. I08-II3.

${ }_{71}^{71}$ La fiesta del patrocino de san José se celebraba en el atardecer con una velada que incluía una conferencia y por la mañana siguiente tenía lugar la misa y el posterior desayuno en la sede del Círculo, El Heraldo de Zamora, I de mayo de I903, p. 3.

72 En una carta el presidente del Círculo Católico de San Martín se mostraba la situación financiera deficitaria pues se debían 202 pesetas y no se habían podido ni siquiera entregar los premios a los alumnos del año anterior: AHDza, Secretaría de Cámara, legajo 368, Carta del presidente del Círculo Católico de San Martín al obispo de Zamora Luis Felipe Ortiz, Zamora, 2I de junio de I899.

73 «Se ha presentado para su aprobación el reglamento de la Caja de Socorros Mutuos», El Heraldo de Zamora, 27 de febrero de I90I, p. 3. También se presentaron y aprobaron las bases para constituir una sociedad anónima que llevase a la práctica el proyecto de unas casas y huertos para obreros, pero, por desgracia, no sabemos más acerca de este interesante iniciativa: El Heraldo de Zamora, I4 de febrero de I902, p. 3.

74 «Mañana se celebrará la fiesta del patrocino de San José con misa rezada y comunión general [...] y se inaugurará una Caja de Socorros para los obreros en casos de enfermedad y defunción», El Heraldo de Zamora, i8 de marzo de I90I, p. 3. La finalidad de esta caja consistía, según el último reglamento aprobado, en proporcionar una pensión o socorro diario a los asociados enfermos; facilitarles la asistencia facultativa y las medicinas necesarias en caso de enfermedad y, en caso de fallecimiento, entregar una cantidad establecida a la viuda, si el asociado estaba casado, y al padre o a la madre, si era soltero; asignar un socorro pecuniario a las madres de familias durante los primeros veinte días siguientes al parto, y constituir pensiones de retiro a favor de los asociados.

75 Hernández Fuentes, Miguel Ángel: En defensa de los sagrados intereses. Historia religiosa de la diócesis de Zamora durante la restauración (I875-19I4), Salamanca, Ediciones de la Universidad de Salamanca, 2016, pp. 606-609. 


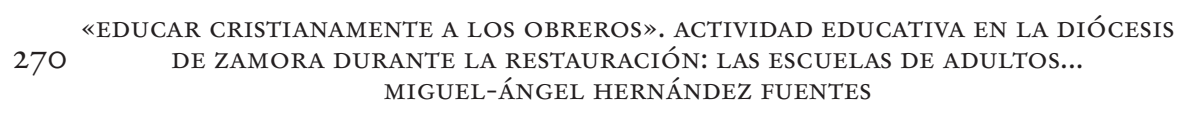

Respecto al objetivo educativo, que es el que nos interesa en este artículo, el Círculo Católico contaba con una década de experiencia suministrada por las Escuelas de Adultos. En este asunto, el Círculo Católico heredaba la actividad docente de las Escuelas Dominicales y Nocturnas, incluyendo otros fines que superaban la actividad meramente instructiva y ampliando su oferta. La preeminencia de esta finalidad educativa era señalada por el obispo Luis Felipe Ortiz, quien definía el Círculo Católico como un «centro de educación y enseñanza donde los obreros adquieren no solo conocimientos científicos, sino también costumbres religiosas de que tan necesitada está nuestra actual sociedad $»^{76}$. Para conseguir que los obreros recibiesen una educación cristiana y una instrucción acomodada a su clase, se establecieron unas «escuelas y academias nocturnas en las que se enseñaba la doctrina cristiana, lectura, escritura, gramática, geografía e historia, aritmética, geometría aplicada a las artes, dibujo lineal figurado y de adorno, modelado y otras asignaturas» ${ }^{77}$. Al frente de estas materias estuvieron diversos profesores que formaban parte del ámbito educativo de la capital y que gozaban de cierta popularidad local como Gabriel Fuentes, un pintor premiado en varias exposiciones regionales que tenía por aquellas fechas una academia de Dibujo en Zamora ${ }^{7}$ o el catedrático auxiliar de obras públicas, Luis Gamboa, que fue profesor de dibujo en el citado centro católico ${ }^{79}$. Con estas clases se trataba de instruir cultural y profesionalmente a los obreros y formarlos en el ejercicio de las virtudes cristianas pues la educación cristiana, junto a la profesional, planeaba siempre sobre esta actividad:

Educar cristianamente a los obreros, facilitar la mayor cultura general posible y la especial que convenga al oficio o arte al que se dediquen, ilustrar su entendimiento para que juzguen las cuestiones sociales, hoy tan discutidas, con el criterio de rectitud y sensatez que nace de las enseñanzas de la Iglesia es hacerles el mayor de los favores, es facilitarles el ejercicio de sus legítimos derechos y el cumplimiento de sus ineludibles deberes, es labrar su propia ventura y, en parte, la de la sociedad a que pertenece ${ }^{80}$.

Esta educación se completaba con una serie de conferencias que se ofrecían todos los domingos del prolongado invierno zamorano, desde octubre hasta mayo, y que constituían una de sus actividades más destacadas, suscitando el interés de la población. En estas charlas se abordaba una temática variada pero principalmente religiosa, aunque no faltaron determinadas conferencias en las que se abordaron las propuestas de la encíclica Rerum novarum. Estas últimas despertaron, en algunos casos, el entusiasmo de los trabajadores y el rechazo del sector clerical más tradicionalista. Así lo señalaba El Heraldo de Zamora tras acudir a una conferencia pronunciada por el padre Ciarán, un joven dominico

76 «Una velada», El Heraldo de Zamora, io de mayo de 1904, p. I.

77 Reglamento reformado del Círculo Católico..., art. Io. ${ }^{\circ}$.

78 El Heraldo de Zamora, 26 de septiembre de I90o, p. 3.

79 El Heraldo de Zamora, 4 de octubre de 1902, p. 3.

8o El Heraldo de Zamora, 29 de septiembre de I900, p. I. 
«EDUCAR CRISTIANAMENTE A LOS OBREROS». ACTIVIDAD EDUCATIVA EN LA DIÓCESIS DE ZAMORA DURANTE LA RESTAURACIÓN: LAS ESCUELAS DE ADULTOS... MIGUEL-ÁNGEL HERNÁNDEZ FUENTES

de veintiocho años que acudió a Zamora, procedente de Salamanca, para disertar sobre la cuestión obrera a quien «la numerosa concurrencia», según la crónica del diario, «subyugada y electrizada, le interrumpía frecuentemente con estruendosos aplausos» ${ }^{8 \mathrm{I}}$. Sin embargo, continuaba el cronista, el clero asistente no parecía encontrarse cómodo con lo que escuchaba de labios del dominico:

Parece que asistieron muchas personas ilustradas, entre las que se contaba buen número de presbíteros. De estos, parece que hay algunos a quienes no ha gustado el discurso del dominico, que consideran como socialista. Mas... asáltame una duda, santos varones... No será el socialismo predicado por Fourier, Louis Blanc, Proudhon etcétera, etc., sino el socialismo católico comprendido en la encíclica que nuestro sumo pontífice, el papa León XIII, a vivas instancias de toda la cristiandad, publicó en 15 de mayo de $189 \mathrm{I}^{82}$.

A partir de I906, por un acuerdo de la junta directiva, se fue ampliando el abanico de las materias impartidas en estas conferencias dominicales ${ }^{83}$, lo que, sin duda, contribuyó a aumentar su interés y atrajo a una importante audiencia al centro católico, especialmente cuando acudía un conferenciante de renombre. Si bien el interés principal del Círculo Católico era la instrucción religiosa y moral de sus asociados, los temas que se abordaron en estas conferencias fueron variados y presentaron diversas cuestiones técnicas, morales, económicas y religiosas. A juzgar por el testimonio del diario liberal de Zamora, que no era ni el promotor, ni el valedor de estas actividades, las conferencias tenían mucho éxito y, sin duda, suponían un momento de convivencia en las tardes de los fríos domingos del invierno zamorano. No disponemos de un catálogo de todas las conferencias, pero la prensa nos ha suministrado algunos títulos de los que podemos ofrecer aquí un elenco:

Tabla I. Algunos temas tratados en las conferencias del Círculo Católico de Zamora durante los primeros años del siglo $X X$

\begin{tabular}{|l|l|}
\hline TEMA & PONENTE \\
\hline Ventajas que ofrece el Instituto Nacional de Previsión & Santos Pascual, párroco de San Torcuato \\
\hline La casa del obrero & Dacio Crespo, médico. \\
\hline Las reglas de la aritmética & Catedrático del Instituto de Zamora \\
\hline La tuberculosis y los medios higiénicos de evitarla & $\begin{array}{l}\text { Antonio Crespo y Carro, director de los } \\
\text { establecimientos de beneficencia }\end{array}$ \\
\hline El ahorro & Enrique Gallego Gutiérrez, abogado y sacerdote \\
\hline La importancia del arbolado & Antonino García Fernández \\
\hline La Maragatería & Joaquín de Ciria, de la Real Sociedad Geográfica \\
\hline $\begin{array}{l}\text { La infancia abandonada viciosa delincuente en sus tres } \\
\text { aspectos, social, económico y jurídico, sus causas y su } \\
\text { remedios }\end{array}$ & Manuel Alonso Ledesma, subjefe de la cárcel de Zamora \\
\hline
\end{tabular}

8. El Heraldo de Zamora, 4 de mayo de I900, p. 2.

82 Ibidem.

${ }_{83}$ El Heraldo de Zamora, 1906 de octubre de 29, pp. 2-3. 
«EDUCAR CRISTIANAMENTE A LOS OBREROS». ACTIVIDAD EDUCATIVA EN LA DIÓCESIS

272 DE ZAMORA DURANTE LA RESTAURACIÓN: LAS ESCUELAS DE ADULTOS... MIGUEL-ÁNGEL HERNÁNDEZ FUENTES

\begin{tabular}{|l|l|}
\hline TEMA & PONENTE \\
\hline $\begin{array}{l}\text { Las dos democracias, socialista y cristiana, frente al } \\
\text { problema social }\end{array}$ & Emilio Martín Castilla, sacerdote \\
\hline Sobre la educación & $\begin{array}{l}\text { Eulalio Escudero Esteban, inspector jefe de Primera } \\
\text { Enseñanza }\end{array}$ \\
\hline Sobre los seguros de retiro obrero & $\begin{array}{l}\text { Domingo Regidor Simón, agente de fomento del } \\
\text { Instituto Nacional de Previsión }\end{array}$ \\
\hline La familia: su carácter & Eulalio Escudero Esteban \\
\hline Retiros de obreros y mutualidades escolares & $\begin{array}{l}\text { José G. Castro, profesor de economía política de la } \\
\text { Universidad de Salamanca }\end{array}$ \\
\hline Urbanización y construcción & Segundo Viloria, arquitecto. \\
\hline
\end{tabular}

Fuente: El Heraldo de Zamora y El Correo de Zamora.

Para incentivar la lectura de los obreros, existía en el Círculo una biblioteca con revistas y periódicos católicos $\left(\right.$ art. II. $^{\circ}$ ) y, con el fin de estimular su aprendizaje, se convocaban premios en certámenes de artes y oficios cuyos galardones se entregaban con motivo de las veladas literarias que tenían lugar en la fiesta de la Inmaculada, de san José o en la clausura del curso (art. I2. ${ }^{\circ}$ ). Por último, para el cumplimiento del fin recreativo, se habilitaron unos salones para el esparcimiento de los socios. Unos se utilizaban para los juegos, juegos lícitos que contaban con la aprobación de la junta directiva, y otros para la celebración de actos públicos, como las veladas artísticas o literarias, las funciones teatrales o cinematográficas ${ }^{84}$. Dentro de estas actividades, también se creó un orfeón que actuaba en diversas ocasiones y sobre todo en Semana Santa ${ }^{85}$. Con todas estas actividades se pretendía fomentar «la afición al Círculo y la mutua compenetración de todos los socios ${ }^{86}$. Sería interesante poder sondear la efectividad de tales medidas, pero no disponemos de documentación suficiente para ello, aunque sabemos que el Círculo Católico Obrero tuvo una importante incidencia en la vida diocesana y social de Zamora, siendo una de las instituciones que pesaban más en la representación institucional de actos eclesiásticos y civiles. Incluso llegaron a presentar a diversos candidatos al Consistorio para el que obtuvieron sucesivas actas de concejal en los comicios electorales celebrados entre 1913 у 1920.

Respeto al sostenimiento económico, el Círculo se financiaba con la cuota de los «socios protectores», que aportaban sus donativos conforme a la mentalidad paternalista del momento. Sin embargo, tras unos inicios esperanzadores, estos donantes disminuyeron y las reiteradas peticiones de la junta directiva fueron desoídas:

${ }_{84}$ Entre esas actividades podemos contar también la merienda que los obreros tenían con el obispo, quien los invitaba, para celebrar la Pascua, algo que contribuía, sin duda, a aumentar la sintonía afectiva de los católicos con su prelado que terminaban en manifestaciones de entusiasmo: «Durante la merienda reinó la expansión y la alegría propia de los banquetes de la gente joven y, al final, fueron muchos los vivas que los comensales dieron al señor obispo, a la Junta del Círculo y a su presidente», El Heraldo de Zamora, 9 de abril de I9oI, p. 2.

85 El Heraldo de Zamora, 8 de abril de I9I4, p. 2.

86 Reglamento reformado del Círculo Católico..., art. I4. 
«EDUCAR CRISTIANAMENTE A LOS OBREROS». ACTIVIDAD EDUCATIVA EN LA DIÓCESIS DE ZAMORA DURANTE LA RESTAURACIÓN: LAS ESCUELAS DE ADULTOS... MIGUEL-ÁNGEL HERNÁNDEZ FUENTES

«Nadie se ha movido para hacerse suscriptor, protestaba su presidente, se han repartido circulares en varias ocasiones, exponiendo la necesidad de recursos pecuniarios: nulo el resultado» ${ }^{87}$. La cantidad recaudada en 1897 por las cuotas de los socios quedaron reducidas a I73 pesetas mensuales con las cuales, según su director, era imposible sostener las enseñanzas impartidas a los doscientos obreros:

Hace seis años se fundó el Círculo Católico Obrero, tomáronle muchas personas con relativo entusiasmo y sus principios parecieron augurarle vida larga y exuberante, porque desgraciadamente las gentes se cansan luego de trabajar y de prestar medios de vida a instituciones sociales de grandísima importancia y digo esto porque no es solo el Círculo el que padece la anemia de personal y de recursos, sino también otra asociaciones de las que no he de hablar al presente ${ }^{88}$.

Ante esta carencia de benefactores, el obispo tuvo que apoyar económicamente la actividad docente y en 1900 hubo de financiarla totalmente con el erario diocesano $^{89}$. Para paliar este déficit y para sostener una iniciativa social que reportaba también un beneficio a la ciudad, el Ayuntamiento comenzó a incluir en sus presupuestos anuales la cantidad de 250 pesetas con el fin de sostener económicamente su enseñanza. Esta partida presupuestaria muestra una vez más el carácter eminentemente instructivo del Círculo Católico, pues su aplicación a la docencia era lo que el Consistorio exigía para su concesión del mismo modo que hacía con otros establecimientos semejantes ${ }^{90}$. No obstante, la concesión de esta cantidad estuvo sometida a debate constante, y era común que en el pleno municipal se sacara de los presupuestos y volviera a incluirse posteriormente ${ }^{91}$.

Estas dificultades económicas nos permiten ofrecer una última valoración del desarrollo de esta actividad, que comenzó con entusiasmo en i89i y que, unos años después, languidecía por la falta de apoyo, de interés de sus asociados o de un proyecto social más ambicioso que superase la mera instrucción. Quizá unas de las razones de su escaso éxito fue que, durante sus primeros años de existencia, apenas superó su carácter educativo y en la escasa documentación de que disponemos

${ }^{87}$ Firmat, Jesús: «El Círculo Católico Obrero», El Heraldo de Zamora, in de diciembre de I897, p. 2.

${ }_{88}$ Ibidem.

89 El Heraldo de Zamora, 29 de septiembre de 1900, p. I.

9० El Heraldo de Zamora, io de noviembre de i9ıo, p. 2.

9r En 1907, el concejal Funcia pidió un recorte de subvenciones con el fin de sanear la economía municipal y entre ellas estaba la supresión de las 250 pesetas concedidas al Círculo Católico Obrero, pero en una ulterior discusión se acordó su entrega: El Heraldo de Zamora, i8 de diciembre de 1907, p. 2 y 24 de noviembre de I903, p. I. En I9Io se suprimieron las subvenciones concedidas a la Conferencia de San Vicente de Paúl y al Círculo Católico Obrero fundándose en que otras sociedades semejantes las habían solicitado y no se les podía atender: El Heraldo de Zamora, 3 de noviembre de İıo, p. I. Sin embargo, unos días después se acordó su concesión. El señor Funcia impugnó estas partidas, por entender que otras entidades tenían el mismo derecho y no se les podía conceder por escasez de fondos. No obstante, la Corporación consignó otras 250 pesetas para el Centro de las Sociedades Obreras si justificaban su empleo para la instrucción, El Heraldo de Zamora, io de noviembre de i9ı, p. 2. 


\section{«EDUCAR CRISTIANAMENTE A LOS OBREROS». ACTIVIDAD EDUCATIVA EN LA DIÓCESIS 274 DE ZAMORA DURANTE LA RESTAURACIÓN: LAS ESCUELAS DE ADULTOS... MIGUEL-ÁNGEL HERNÁNDEZ FUENTES}

parece que no había mucha diferencia con las antiguas Escuelas Dominicales o Nocturnas para obreros ${ }^{92}$. Esta falta de apoyo era señalada por su director, Jesús Firmat, en el artículo antes señalado, quien recordaba el auge que la institución tuvo en sus orígenes y se lamentaba de la situación que atravesaba a tan solo cinco años de su fundación. La queja no nacía por la falta de alumnos, pues parece que el número de obreros participantes se mantuvo en los dos centenares, sino por la falta de apoyo económico y de socios honorarios. Ante esta situación, El Correo de Zamora reclamaba la colaboración activa de las Conferencias de San Vicente de Paúl, pues esta institución benéfica tenía más personal y un mayor volumen de actividad $^{93}$. También el diario liberal, El Heraldo de Zamora, manifestaba su pesar por el declive de una institución dedicada a la educación de los obreros y señalaba algunas causas que impedían su desarrollo:

La falta de entusiasmo propia de nuestro carácter, la crisis económica que atraviesa el país, y sobre todo el no haberse sentido hasta ahora los males sociales que en otras partes son formidable amenaza o terrible castigo, han hecho que por las clases acomodadas no se atienda todo lo debido a fomentar este remedio, el más eficaz para evitar aquellos males ${ }^{94}$.

Al margen de las razones señaladas, este texto pone de manifiesto algunas de las características que acompañaron a los Círculos Católicos desde sus primeros años de existencia. La primera era el carácter prioritariamente instructivo, pues, hasta entrado el siglo xx, el Círculo no era más que una prolongación de las Escuelas de Adultos que hacían de la misión educativa su principal soporte y la respuesta prioritaria ante la cuestión obrera. La segunda característica era el paternalismo con que se entendía este tipo de actividades, que debían impulsar y apoyar las clases acomodadas a favor de las menesterosas. Así lo había manifestado también su director en el artículo antes citado donde, para pedir el apoyo económico de los pudientes zamoranos, decía lo siguiente: «No olviden las clases acomodadas que la religión es el foco de las virtudes, la base de las costumbres públicas, consuelo de los afligidos y medio más eficaz que el amor de la patria para la conservación del orden social»" ${ }^{95}$. Este apoyo económico al Círculo no solo era pedido por caridad, sino «para procurar el orden social», pues, según su director, la participación de los obreros en las actividades del Círculo evitaría que las clases populares fueran víctimas de «nocivas doctrinas y perversas intenciones» que condujeran a todos a la catástrofe como había ocurrido en varias ciudades europeas ${ }^{96}$. Por último, el artículo que estamos comentando señalaba la escasa conflictividad obrera sentida en Zamora hasta la fecha, lo que sin duda contribuyó a retrasar una propuesta social católica más decidida en este campo. Unos años

92 «En el Círculo Católico Obrero», El Heraldo de Zamora, 5 de abril de I903, p. 2.

93 El Correo de Zamora, i de abril de i899, p. I.

94 «El Círculo Católico de Obreros», El Heraldo de Zamora, 29 de septiembre de I900, p. I.

95 Firmat, Jesús: «El Círculo Católico de Obreros», El Heraldo de Zamora, in de diciembre de 1897, p. 2.

96 Idem. 
«EDUCAR CRISTIANAMENTE A LOS OBREROS». ACTIVIDAD EDUCATIVA EN LA DIÓCESIS DE ZAMORA DURANTE LA RESTAURACIÓN: LAS ESCUELAS DE ADULTOS... MIGUEL-ÁNGEL HERNÁNDEZ FUENTES

después, tras la llegada del siglo xx el Círculo Católico superó esta crisis con el incremento de actividades. Ciertamente, la creación de la Caja de Socorros $\mathrm{Mu}-$ tuos en I9or y la formación de los sindicatos católicos en i913 dieron un notable impuso al Círculo Católico Obrero, superando la crisis en que se vio sumido en torno a I900, pero su estudio en profundidad supera la pretensión de este artículo.

\section{Conclusiones}

Como puede verse, durante sus primeros años de existencia, el Círculo Católico Obrero de Zamora fue principalmente un centro educativo que heredó la actividad de las Escuelas de Adultos e incrementó sus objetivos y sus medios con la inclusión de determinadas actividades religiosas, literarias y de recreo. Con ellas se pretendía preservar a los trabajadores de los peligros del socialismo y de las doctrinas, consideradas por la literatura pastoral, como disgregadoras de la sociedad y peligrosas para la fe. No creemos que estos peligros fueran muy fuertes en Zamora, pero existían para la mentalidad católica del momento que defendía una solución a la cuestión obrera sin perder la armonía social entre las clases ${ }^{97}$. También las noticias que salían en la prensa y el eco llegado de otras latitudes exigían inocular pronto el antídoto. Ambas instituciones, Escuelas de Adultos y Círculo Católico de Obreros, deben ser estudiadas, al menos en la diócesis de Zamora, como un único proyecto que fue dando sus pasos y ampliando sus funciones para responder a las directrices de la doctrina social de la Iglesia y adaptarse a los nuevos retos.

En ellas se educaba al obrero mediante la docencia de determinadas materias que elevasen su nivel educativo y lo apartasen del analfabetismo, como la aritmética, la lectura o la escritura, y mediante charlas y conferencias de temática variada que le permitieran ensanchar sus conocimientos. No eran centros puramente doctrinales, como se ha mostrado en las páginas precedentes, aunque la enseñanza de la doctrina cristiana fuera parte importante de su actividad. Algunos autores han señalado el propósito ideológico de la Iglesia a la hora de impulsar estos centros educativos, lo cual no resta valor a su actividad, sino que le da sentido: las Escuelas para Adultos y los Círculos Católicos no eran centros estatales o proyectos neutros de educación popular, sino que su existencia se inscribe en el programa propio que la Iglesia debía desarrollar: la evangelización. Frente a los retos de la secularización, la acción social de la Iglesia pretendía mantener a los obreros en el seno de la comunidad cristiana y, en Zamora, logró en gran parte su propósito a

${ }_{97}$ Los obreros zamoranos celebraban el primero de mayo desde comienzos del xx, pero, como señalaba el presidente del gremio de carpinteros de Zamora, la difusión de las ideas socialistas iba creciendo entre las clases obreras que reclamaban una «revolución desde abajo»: El Heraldo de $\mathrm{Za}$ mora, I de mayo de I903, p. 2. Sin duda estas noticias alarmaban al obispo. No eran manifestaciones anticlericales o no tenemos noticia de que lo fueran, pero las ideas allí manifestadas iban contra la doctrina católica: la amenaza de huelga o la lucha de clase eran vistas por la Iglesia como una amenaza para el orden social. 
la vista de los resultados ${ }^{9}$. Para ello, la educación popular no puede considerarse de modo aislado, sino que debe contemplarse como una pieza más del proyecto católico por el que se desarrollaba la misión de la Iglesia en el mundo laboral. Los obreros eran objeto de la acción educativa de la Iglesia, pero también eran convocados a incrementar su devoción participando en los actos piadosos que jalonaban el año, a adaptar su conducta a la moral católica o a movilizarse en defensa de la fe, sumándose a las peregrinaciones y a las otras actividades convocadas desde el Obispado. En resumen, con sus límites y carencias, podemos decir que las instituciones educativas populares desarrolladas en Zamora cumplieron una misión que no era puramente social o económica, sino religiosa y esta misión la hemos de ver inserta en el programa global que la Iglesia tenía en este momento: el mantenimiento de la fe y de la moral católica en una sociedad cambiante que tenía un enemigo principal: la secularización.

98 Véanse los datos sobre la evolución del cumplimiento pascual en la diócesis: Hernández Fuentes, Miguel Ángel: En defensa de los sagrados intereses..., pp. 773-794. 